\title{
Studies of new occurrences of bentonite clays in the State of Paraíba for use in water based drilling fluids
}

\section{Estudos de novas ocorrências de argilas bentoníticas do Estado da Paraíba para uso em fluidos de perfuração base água}

\begin{abstract}
Isabelle A. Silva
Aluna de Pós-Graduação em

Ciência e Eng. de Materiais, UFCG.

isabelle_albuquerquecg@hotmail.com

Julliana Marques R. Costa

Aluna de Pós-Graduação em

Ciência e Eng. de Materiais, UFCG.

jullymrc@gmail.com
\end{abstract}

\section{Romualdo R. Menezes}

Pesquisador Dr.,

Unidade Acadêmica de Eng. de Materiais, UFCG. romualdomenezes@dema.ufcg.edu.br

\section{Heber S. Ferreira}

Professor Dr.,

Departamento de Eng. de Materiais, UFPB.

hebersivini@ig.com.br

Gelmires de A. Neves

Professor Dr.

Unidade Acadêmica de Eng. de Materiais, UFCG. gelmires@dema.ufcg.edu.br

Heber C. Ferreira

Professor Dr.,

Unidade Acadêmica de Eng. de Materiais, UFCG. heber@dema.ufcg.edu.br.

\section{Resumo}

Recentemente foram descobertos novos depósitos de argilas bentoníticas no Estado da Paraíba principalmente nos municípios de Cubati e Pedra Lavrada, criando uma grande expectativa pela possibilidade de ampliação das novas reservas para produção industrial. $\mathrm{O}$ objetivo desse trabalho foi estudar as novas ocorrências de argilas bentoníticas da Paraíba, principalmente do município de Pedra Lavrada, para uso em fluidos de perfuração base água. A caracterização mineralógica foi efetuada através da análise granulométrica por difração de laser, análises termogravimétrica e térmica diferencial, composição química por fluorescência de raios X, difração de raios X, capacidade de troca de cátions e área específica. As argilas bentoníticas foram tratadas com carbonato de sódio nas concentrações de 75, 100,125,150 e 175meq/100g de argila seca, para sua transformação da forma policatiônica para forma sódica. Para caracterização tecnológica, foram confeccionados fluidos de perfuração de acordo com as normas da Petrobras. Os resultados obtidos evidenciaram que as amostras estudadas apresentaram, na sua composição mineralógica, montmorilonita, caulinita e quartzo. Em relação às propriedades reológicas, verificou-se que as amostras estudadas atendem parcialmente aos requisitos reológicos da norma da Petrobras.

Palavras-chave: Argila bentonítica, caracterização, fluidos de perfuração.

\begin{abstract}
New bentonite clay deposits have recently been discovered in the state of Paraiba, mainly in the municipalities of Cubati and Pedra Lavrada, creating great expectations in view of the possibility of expanding industrial production using these new reserves. The aim of this study was to study the new occurrences of bentonite clay in Paraiba, particularly in the municipality of Pedra Lavrada, for use in water based drilling fluids. The mineralogical properties of the clays were characterized by particle size analysis using laser diffraction, and thermogravimetric and differential thermal analysis, and its chemical composition was analyzed by X-ray fluorescence, $X$-ray diffraction, cation exchange capacity and specific surface area. The bentonite clays were treated with sodium carbonate at concentrations of 75, 100, 125, 150 and $175 \mathrm{mEq} / 100 \mathrm{~g}$ of dry clay, to transform them from polycationic to sodium form. For the technological characterization, drilling fluids were prepared according to the standards of Petrobras. The results indicated that the mineralogical composition of the samples consisted of montmorillonite, kaolinite and quartz. As for their rheological properties, the samples were found to partially meet the rheological requirements of the Petrobras standard.

Keywords: Bentonite clay, characterization, drilling fluids.
\end{abstract}




\section{Introduction}

The crystalline structure of bentonite clays is triple-layered, consisting of two tetrahedral sheets and one octahedral sheet. These tetrahedral and octahedral sheets exhibit isomorphic substitution that produces a charge imbalance, generating a cation-exchange capacity (CEC) in the order of $100 \mathrm{mEq} / 100 \mathrm{~g}$ of dry clay. This group comprises four dioctahedral and three trioctahedral clay minerals. The dioctahedral clay minerals are beidellite, nontronite, volkonskoite and montmorillonite, and the trioctahedral clay minerals are saponite, sauconite and hectorite (Souza Santos, 1992; Silva and Ferreira, 2008 and 2009).

Bentonite clays are produced by the decomposition of volcanic ash in alkaline environments with restricted water circulation, and their predominant clay mineral is montmorillonite (Souza Santos, 1992; Silva and Ferreira, 2008 and 2009).

It should be noted that bentonites are composed mainly of the clay mineral montmorillonite. The complexity of these concepts leads to constant misinterpretation. To further complicate the issue, Souza Santos (1992) stated that montmorillonite clays used industrially as bentonites, regardless of their geological origin, can be called bentonites. In the same vein, we should mention the work of Golpinath, Schuster and Schuckmann (1981 and 1988), who showed that montmorillonite clays from the region of the municipality of Boa Vista, state of Paraíba, and surroundings are bentonites. Thus, in

\section{Materials and methods}

\section{Materials}

The following clay samples were used: Grey Clay, Light Clay, Green Clay

and Dark Bentonite Clay, from deposits located in the municipality of Pedra

\section{Methods}

The samples were dried at room temperature for approximately four days, after which they were milled in a ball mill lined with a very hard ceramic material. The milled materials were then sifted through an electric sieve (Pavitest I-3007) (0.074 $\mathrm{mm}$ sieve opening). Aliquots of the sifted materials were removed for the various physical, chemi$\mathrm{cal}$, and mineralogical characterizations, and to test their use in water based drilling fluids. this paper, the clays under study will be referred to as bentonites.

Bentonite may be calcium or sodium bentonite, and in its sodium form it presents a very particular physical characteristic, i.e., its volume expands many times over when in contact with water, forming thixotropic gels (Souza Santos, 1992; Bernier et al., 2003; Sousa, 2010; Menezes et al., 2008).

Bentonite is used industrially for various purposes, e.g., as a viscosity modifier of oil drilling fluids, as a sand casting binder, as an iron ore pelletizer, in sanitary napkins for pets, and as an oil bleacher, 1996; Mahto and Sharma, 2004; Amorim et al., 2002; Coelho and Souza Santos, 2007; Campos 2007; Menezes et al., 2009; Menezes et al., 2010).

Several researchers of the Academic Unit of Materials Engineering at the Federal University of Campina Grande - UFCG, Brazil have been conducting research into the use of bentonite clay in oil drilling fluids. These studies include that of Amorim (2003), who worked on samples of natural bentonite clays and industrialized sodium clays from deposits in Boa Vista, PB, aiming to improve their rheological behavior and obtain contamination resistant water and clay-based fluids. The results indicated that the different behaviors presented by dispersions, after protection and recovery treatments, can be very useful to optimize the application of these clays in drilling fluids. among others uses (Caenn and Chillingar,
Campos (2007) studied compositions of bentonite clays in deposits in the municipality of Boa Vista, PB, aiming to potentiate the utilization of poor quality clays in oil drilling fluids. The results confirmed that studies of clay compositions can be very useful for the clay miners and beneficiation industry of Boa Vista, as well as for the crude oil sector, given the possibility of using poor quality clay, which is available in large quantities in bentonite deposits, in oil drilling fluids.

Sousa (2010) studied compositions of organophilic clays for organic based drilling fluids containing the following additives: dispersants, emulsifiers, brine, activator, filtrate reducer, and densifiers, in order to evaluate their rheological behavior, filtration and electrical stability. The results demonstrated that two of the developed compositions show a promising potential that meets the specifications of Petrobras.

Ferreira (2009) studied the organophilization of bentonite clays from Boa Vista, $\mathrm{PB}$, for use as viscosity modifiers of oil-based drilling fluids. His findings indicated the importance of process variables to the organophilization process and the rheology of dispersions for use in drilling fluids.

The objective of this work was to study the new occurrences of bentonite clays in the municipality of Pedra Lavrada, state of Paraíba, Brazil, for use in water based drilling fluids.
Lavrada, PB.

(CEC) and specific surface area (SSA) (using the methylene blue adsorption method described by Chen et al., 1974).

After the characterization tests, the bentonite clays, which naturally contain many different cations, were transformed into sodium bentonite by contact with concentrated sodium carbonate $\left(\mathrm{Na}_{2} \mathrm{CO}_{3}\right)$ solutions in the following concentrations: $75,100,125,150$ and $175 \mathrm{mEq} / 100 \mathrm{~g}$ of dry clay. The degree of fineness and moisture content were then determined. 
The rheological properties of apparent viscosity (AV) and plastic viscosity (PV) were determined, using a Fann 35A vis-

\section{Results and discussion}

Table 1 and Figure 1 describe the particle size distribution of the clays under study, whose distribution curve is monomodal (Gray and Light Clays) or bimodal (Green Clay and Dark Bentonite). The latter show a concentration of particles between 2 and $9 \mu \mathrm{m}$, with a mean diameter smaller than $3.29 \mu \mathrm{m}$ for the Grey Clay and larger than $12.25 \mu \mathrm{m}$ for the Dark Bentonite.

In addition, a high cumulative vol- cometer. Filtrate volume was determined by filtration through a Fann filter press, and $\mathrm{pH}$ in a Hanna electronic $\mathrm{pH}$ meter.
All the tests were performed according to the Petrobras EP-1EP-00011-A standard (2011).

\begin{tabular}{c|c|c|c|c}
\hline Samples & $\begin{array}{c}\text { Clay (\%) } \\
(\mathbf{x}<\mathbf{2} \boldsymbol{\mu} \mathbf{m})\end{array}$ & $\begin{array}{c}\text { Silt } \mathbf{( \% )} \\
(\mathbf{2} \boldsymbol{\mu} \mathbf{m}<\mathbf{x}<\mathbf{2 0} \boldsymbol{\mu m})\end{array}$ & $\begin{array}{c}\text { Sand }(\mathbf{\%}) \\
(\mathbf{x}>\mathbf{2 0} \boldsymbol{\mu m})\end{array}$ & $\begin{array}{c}\text { Mean Size } \\
(\boldsymbol{\mu} \mathbf{m})\end{array}$ \\
\hline Grey Clay & 45,88 & 53,97 & 0,15 & 3,29 \\
\hline Light Clay & 19,03 & 74,68 & 6,29 & 7,35 \\
\hline Green Clay & 47,23 & 43,99 & 8,78 & 6,27 \\
\hline Dark Bentonite Clay & 9,26 & 71,03 & 19,71 & 12,25 \\
\hline
\end{tabular}

ume percentage was found to have a mean diameter smaller than $2.0 \mu \mathrm{m}$, which was equivalent to $47.0 \%$ for the Green Clay (corresponding to the clay fraction) and to only $9.0 \%$ for the Dark Bentonite Clay. In terms of accumulated volume of silt (particle diameter larger than $2 \mu \mathrm{m}$ and smaller than $20 \mu \mathrm{m}$ ), the Light and Dark Bentonite clays showed values above $71.0 \%$, while the Green and Gray clays showed lower values of $44.0 \%$ and $54.0 \%$, respectively.
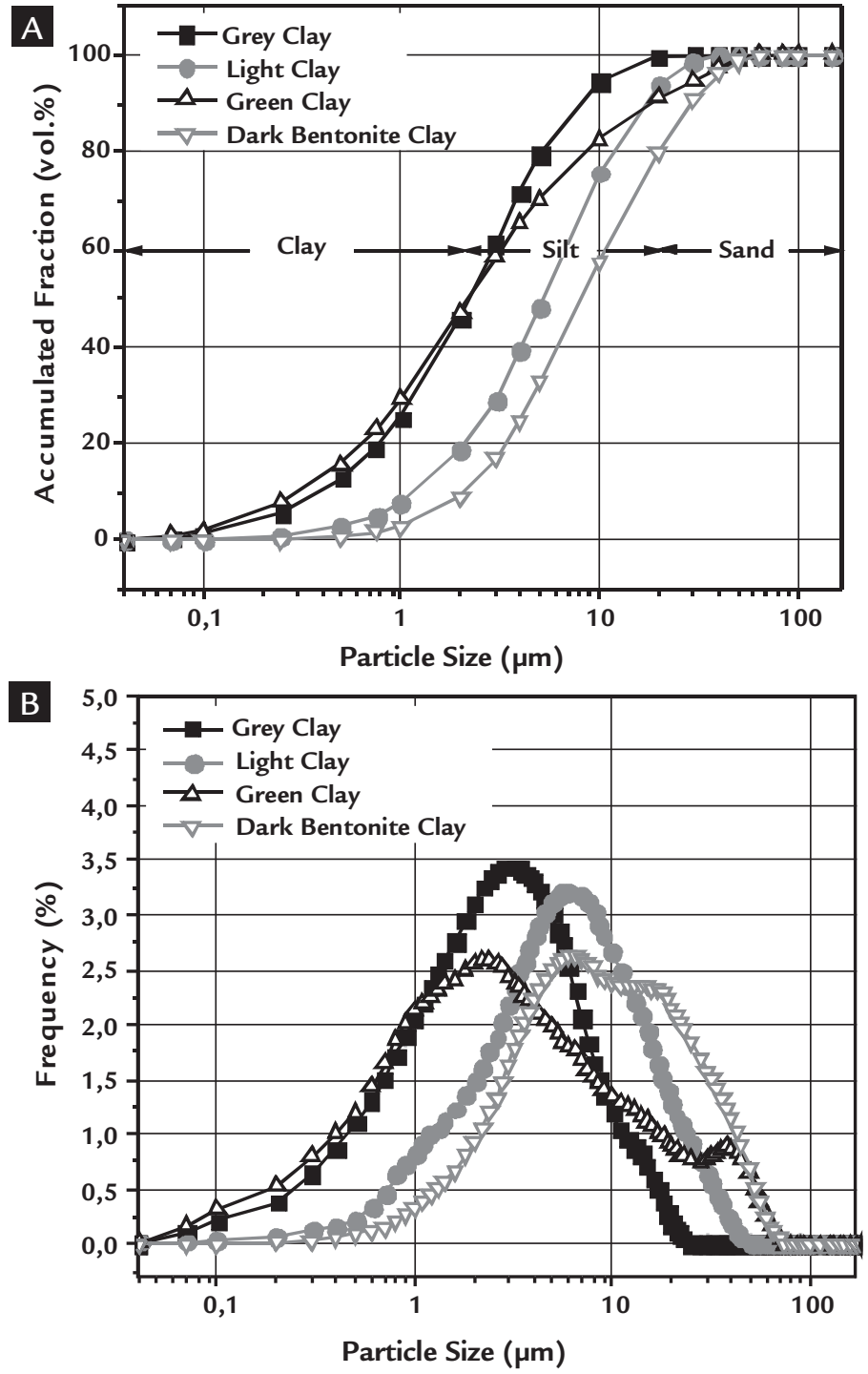

A comparison of the particle size distribution reported by Ferreira (2009) for Chocolate Bentonite clays from Boa Vista, PB, and the Light clay from Pedra Lavrada,PB, reveals very similar results, thus indicating that the physical characteristics of this sample will probably be similar to those of the bentonites from Boa Vista, PB.

Figure 2 shows the TGA and DTA curves of the clays of this study. An

Table 1

Particle size distribution and average particle diameter of the samples.
Figure 1

Particle size distribution of the clays: cumulative volume $(A)$, histogram (B). 
analysis of the curves in Figure 2A reveals the following thermal transformations: an endothermic peak at around $150^{\circ} \mathrm{C}$, characterizing the presence of free and adsorbed water; an exothermic band between 200 and $500^{\circ} \mathrm{C}$, corresponding to the combustion of organic matter (in the Gray and Light clays); an endothermic peak at around $520^{\circ} \mathrm{C}$, characterizing the presence of hydroxyls and an exothermic peak at around $930^{\circ} \mathrm{C}$, characterizing the nucleation of mullite due to the high kaolinite content, as will be seen in the XRD tests. The TGA curves in Figure $2 \mathrm{~B}$ indicate total mass losses of $17.6 \%$, $19.2 \%, 18.8 \%$ and $19.5 \%$, respectively, which correspond to losses in water, organic matter and hydroxyls. A comparison of the results of our thermogravimetric analysis with those reported by Menezes et al. (2009) for bentonites from Cubati, PB shows that they are similar.

Table 2 presents the chemical compositions of the samples under study. An analysis of the results in Table 2 indicates that the clays had high $\mathrm{SiO}_{2}(>45 \%)$ and $\mathrm{Al}_{2} \mathrm{O}_{3}(>25 \%)$ contents. The Gray and Green Clays presented 6.9\% and 7.0\% of $\mathrm{Fe}_{2} \mathrm{O}_{3}$ content, respectively, while that of the other clays was lower than $5.0 \%$.

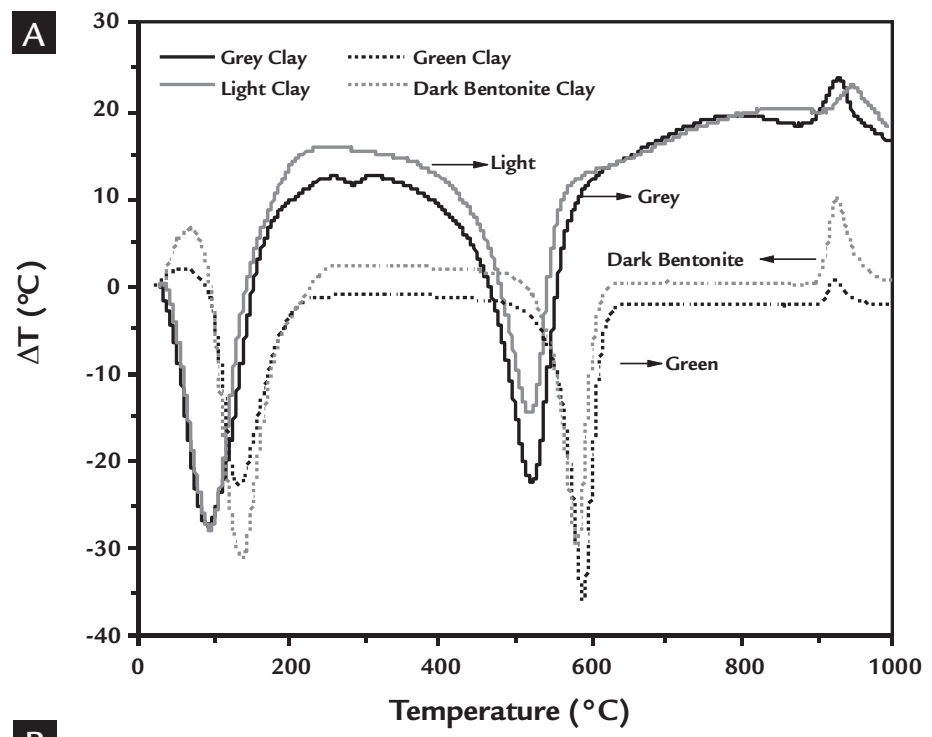

Figure 2

Thermal analysis of the samples:

A) DTA,

B) TGA.

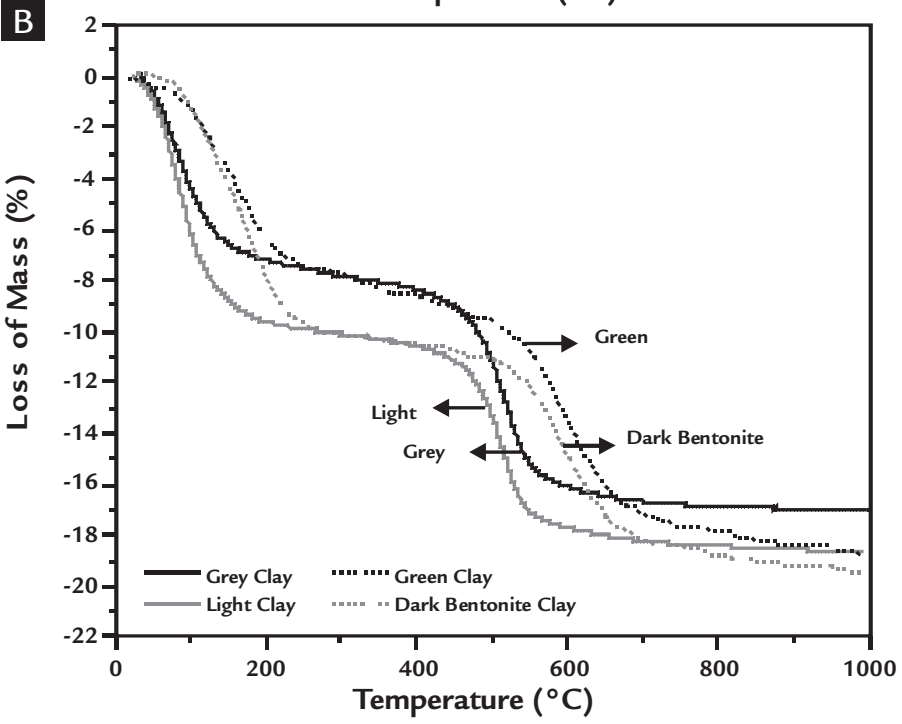

\begin{tabular}{c|c|c|c|c}
\hline & Grey Clay & Light Clay & Green Clay & Dark Bentonite Clay \\
\hline $\mathrm{SiO}_{2}$ & 49,4 & 55,0 & 44,3 & 45,2 \\
\hline $\mathrm{Al}_{2} \mathbf{O}_{3}$ & 31,4 & 30,0 & 25,0 & 27,8 \\
\hline $\mathrm{Fe}_{2} \mathbf{O}_{3}$ & 6,9 & 3,2 & 7,0 & 3,9 \\
\hline $\mathbf{M g O}$ & 1,8 & 2,2 & 1,9 & 2,0 \\
\hline $\mathrm{CaO}$ & 0,1 & 0,5 & 0,0 & 0,4 \\
\hline $\mathbf{K}_{2} \mathbf{O}$ & 0,6 & 0,5 & 1,7 & 0,3 \\
\hline $\mathrm{TiO}_{2}$ & 1,3 & 1,0 & 0,8 & 0,9 \\
\hline LOI* & 8,0 & 7,3 & 18,8 & 19,5 \\
\hline Others & 0,6 & 0,3 & 0,6 & 0,1 \\
\hline
\end{tabular}

Chemical composition of the samples under study.

*LOI - Loss on Ignition 
According to Amorim (2003), an iron content of about $7.0 \%$ is typical of clays from the municipality of Boa Vista, PB. Souza Santos (1992) stated that these iron contents come from bentonite containing about 4.0 to $6.0 \%$ of $\mathrm{Fe}_{2} \mathrm{O}_{3}$. The $\mathrm{K}_{2} \mathrm{O}$ and $\mathrm{TiO}_{2}$ contents were relatively low, i.e., lower than $2 \%$. Comparing the values reported by Amorim (2003) and Souza Santos (1992), we found that the chemical composition of the clays is typical of bentonite clays.

Figure 3 presents the XRD results of the clays studied here. Figure 3 shows that the samples presented the following mineral phases: smectites (montmorillonite), characterized by $15.201 \AA, 4.48 \AA$

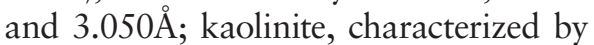
interplanar distances of $7.15 \AA$, $3.566 \AA$, $3.365 \AA, 2.553 \AA, 2.331 \AA$ and $1.892 \AA$; and quartz, characterized by $4.26 \AA, 2.166 \AA$, $1.817 \AA$ and $1.672 \AA$. The presence of smectite (montmorillonite) was confirmed by testing with ethylene glycol (Souza Santos, 1992). Thus, it can be stated that, in general, these clays contain large quantities of kaolinite. The Dark Bentonite clay sample showed a slightly lower kaolinite content, which may favor its rheological behavior.

According to Menezes et al. (2009), bentonite clays from the municipality of Cubati, PB present the following mineral phases: montmorillonite, kaolinite and quartz, and are similar to the clays from the municipality of Pedra Lavrada. In general, the Grey, Light, Green and Dark Bentonite clays presented XRD patterns typical of bentonite clays with high kaolinite contents (Souza Santos, 1992; Ferreira, 2009).

Table 3 describes the cation exchange capacity (CEC) of the samples under study, which was determined by the methylene blue method. As can be seen in Table 3, the CEC values of the samples were very similar, except for the Grey clay sample, and were lower than the level of montmorillonite clay mineral in the smectite group due to their high kaolinite content (80 to $150 \mathrm{mEq} / 100 \mathrm{~g}$ ) (Souza Santos, 1992). However, compared with the clays from the municipality of Boa Vista, $\mathrm{PB}$, whose $\mathrm{CEC}$ is $56 \mathrm{meq} / 100 \mathrm{~g}$, according to Ferreira (2009), the results of this study were very similar, i.e., CEC values of 60 to $64 \mathrm{mEq} / 100 \mathrm{~g}$.

Table 4 shows the results of the specific surface area of the samples. In Table 4, note that the specific surface area of all the samples exhibited higher values than those of the montmorillonite clays studied by Ferreira (2009). According to Ferreira (2009), the specific surface area of chocolate type smectite clays from the municipality of Boa Vista, PB, is 437.04 $\mathrm{m}^{2} / \mathrm{g}$. Comparing this value with that of the clays in the municipality of Pedra Lavrada, PB, one finds that the Green and Dark Bentonite clays possess higher values of specific surface area.

Table 5 shows the apparent viscosity (AV), plastic viscosity (PV), $\mathrm{pH}$, filtrate volume, degree of fineness and moisture content of the clay samples. As can be seen in Table 5, the Dark Bentonite showed best results of apparent viscosity (AV), with values of $23 \mathrm{cP}, 22 \mathrm{cP}$ and $19.5 \mathrm{cP}$ for contents of 75,100 and 150 $\mathrm{mEq} / 100 \mathrm{~g}$ of dry clay. A comparison of these values with the Petrobras standards (2011) indicates that the AV is higher
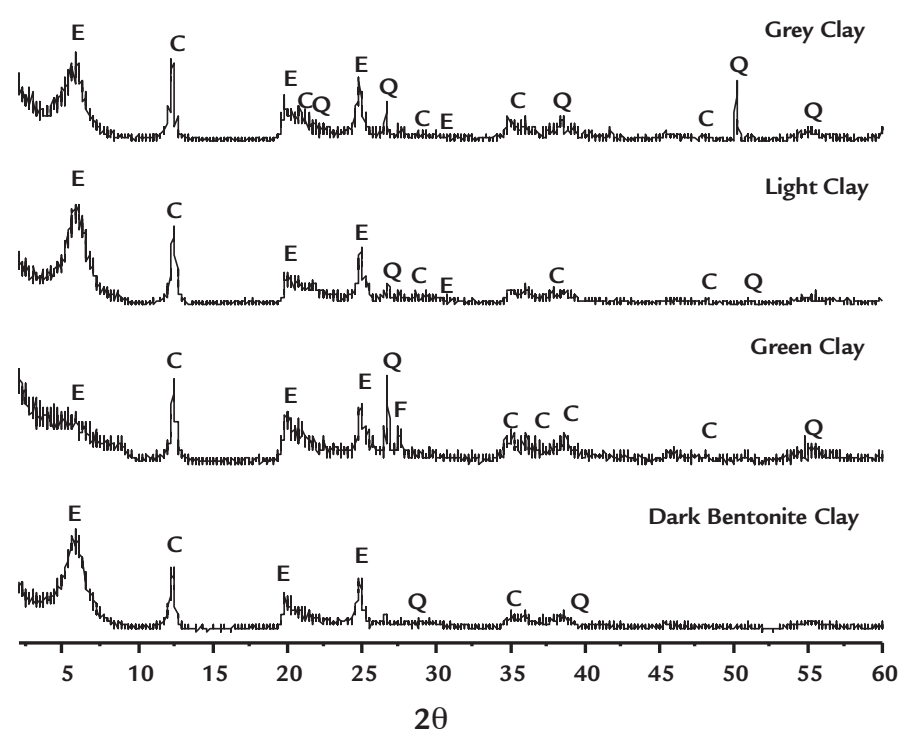

\begin{tabular}{c|c}
\hline Clays & Cation exchange capacity (meq/100g) \\
\hline Grey Clay & 56 \\
\hline Light Clay & 60 \\
\hline Green Clay & 64 \\
\hline Dark Bentonite Clay & 64 \\
\hline
\end{tabular}

\begin{tabular}{c|c}
\hline Amostras & Specific surface area $\left(\mathbf{m}^{2} / \mathbf{g}\right)$ \\
\hline Grey Clay & 437,04 \\
\hline Light Clay & 468,26 \\
\hline Green Clay & 499,47 \\
\hline Dark Bentonite Clay & 499,47 \\
\hline
\end{tabular}

Figure 3

X-ray diffractograms of the clays.

Table 3

Cation exchange capacity of the samples.

Table 4

Specific surface area of the samples. 
than the minimum specified apparent viscosity of $15.0 \mathrm{cP}$. As for plastic viscosity (PV), which, according to Petrobras specifications (2011) cannot be lower than $4.0 \mathrm{cP}$, the Grey clay presented the best results, i.e., a concentration of 150 $\mathrm{mEq} / 100 \mathrm{~g}$. In terms of $\mathrm{pH}$, all the clays are very close to Petrobras specifications (2011) which require a maximum of $\mathrm{pH}$ 10.0. The filtrate volume exceeded the $18.0 \mathrm{~mL}$ specified by the Petrobras standards (2011).

Table 5

Apparent viscosity (AV), plastic viscosity $(\mathrm{PV})$, filtrate volume, degree of fineness and moisture content of the samples.

\section{Conclusões}

Based on this study of new occurrences of smectite clays in the municipality of Pedra Lavrada, PB for possible application in water based drilling fluids, it was
After sifting the samples though an ABNT \# 200 mesh sieve $(0.074 \mathrm{~mm})$, the sieve residue was lower than the maximum of $4.0 \%$ specified by Petrobras. The moisture content of the clays was lower than the maximum of $14.0 \%$ required by the specifications. An overall analysis of the results indicated that none of the samples meets the requirements of Petrobras (2011), and that the dark bentonite clay presented the best results. However, the results of all the samples need to be studied in greater depth, particularly with respect to their rheological properties with additives. According to the studies of Amorim (2003), encouraging results have shown that, with industrial additives, it is likely that suitable responses can be obtained for clay dispersions in the flocculated gel state, which is the case of Dark Bentonite, with an increase in apparent and plastic viscosity and reduction of the filtrate volume, in order to meet the requirements of the standard.

\begin{tabular}{|c|c|c|c|c|c|c|c|}
\hline Samples & $\begin{array}{c}\mathrm{Na}_{2} \mathrm{CO}_{3} \\
\mathrm{meq} / 100 \mathrm{~g}\end{array}$ & $\begin{array}{l}\text { AV } \\
\text { (cP) }\end{array}$ & $\begin{array}{l}\text { PV } \\
(c P)\end{array}$ & $\mathrm{pH}$ & $\begin{array}{c}\text { Filtrate volume } \\
(\mathrm{mL})\end{array}$ & $\begin{array}{c}\text { Degree of } \\
\text { fineness }\end{array}$ & $\begin{array}{c}\text { Moisture } \\
\text { content (\%) }\end{array}$ \\
\hline \multirow{4}{*}{$\begin{array}{l}\text { Grey } \\
\text { Clay }\end{array}$} & 75 & 7,0 & 3,0 & 10,45 & 39,2 & 0 & 4,7 \\
\hline & 100 & 6,0 & 2,0 & 10,49 & 45,6 & 0 & 4,7 \\
\hline & 125 & 6,0 & 3,0 & 10,60 & 48,7 & 0 & 4,7 \\
\hline & 150 & 6,0 & 4,0 & 10,59 & 51,52 & 0 & 4,7 \\
\hline \multirow{4}{*}{$\begin{array}{l}\text { Light } \\
\text { Clay }\end{array}$} & 75 & 5,5 & 2,0 & 10,24 & 32,34 & 0 & 4,0 \\
\hline & 100 & 3,0 & 2,0 & 10,40 & 31,2 & 0 & 4,0 \\
\hline & 125 & 6,0 & 2,0 & 10,43 & 32,63 & 0 & 4,0 \\
\hline & 150 & 6,0 & 2,0 & 10,41 & 35,77 & 0 & 4,0 \\
\hline \multirow{4}{*}{$\begin{array}{c}\text { Green } \\
\text { Clay }\end{array}$} & 75 & 1,5 & 1,0 & 10,68 & 39,50 & 0 & 6,7 \\
\hline & 100 & 0,5 & 0,0 & 10,61 & 52,38 & 0 & 6,7 \\
\hline & 125 & 1,0 & 1,0 & 10,61 & 51,23 & 0 & 6,7 \\
\hline & 150 & 1,5 & 1,0 & 10,57 & 58,67 & 0 & 6,7 \\
\hline \multirow{4}{*}{$\begin{array}{c}\text { Dark } \\
\text { Bentonite } \\
\text { Clay }\end{array}$} & 75 & 23,0 & 2,0 & 9,84 & 35,77 & 0 & 7,3 \\
\hline & 100 & 22,0 & 1,0 & 10,22 & 38,35 & 0 & 7,3 \\
\hline & 125 & 17,0 & 2,0 & 10,26 & 38,64 & 0 & 7,3 \\
\hline & 150 & 19,5 & 2,0 & 10,52 & 41,50 & 0 & 7,3 \\
\hline
\end{tabular}

concluded that the samples presented a mineral composition of montmorillonite, kaolinite and quartz. As for their rheological properties, the samples partially meet the specifications of Petrobras standards (2011) for use in water based drilling fluids, and the Dark Bentonite Clay was found to be the most promising sample.

\section{Referências bibliográficas}

AMORIM, L. V., GOMES, C. M., SILVA, F. L. H., FERREIRA H. C. Comportamento reológico de dispersões de argilas bentoníticas: efeitos do tipo de ferramenta, velocidade e tempo de agitação. Cerâmica, v. 48, n. 308, p.75-85, 2002.

AMORIM, L. V. Melhoria, proteção e recuperação da reologia de fluidos hidroargilosos para uso na perfuração de poços de petróleo. Campina Grande, PB: Curso de Engenharia de Processos/CCT/UFCG, 2003. (Tese de Doutorado).

BERNIER, R., GARLAND, E., GLICKMAN, A., JONES, F., MAIRS, H., MELTON, R., RAY, J., SMITH, J., THOMAS, D., CAMPBELL, J. Environmental aspects of the use and disposal of non aqueous drilling fluids associated with offshore oil \& gas operations. International Association of Oil \& Gas Producers Report, n. 342, Inglaterra, Londres, 2003.

CAMPOS, L. F. A. Composições de argilas bentoníticas para utilização em fluidos de perfuração de poços de petróleo. Campina Grande, PB: Curso de Engenharia de Processos/CCT/UFCG, 2007. 140f. (Tese de Doutorado).

CAENN, R., CHILLINGAR, G. V. Drilling fluids: state of the art. Journal of Petroleum Science and Enginnering, 14, p. 221-230, 1996.

CHEN, T. J., SOUZA SANTOS, P., FERREIRA, H. C., CALIL, S. F., CAMPOS, L.M.V., ZANDONAIDE, A. R., CAMPOS, L.V. Determinação da CTC e da área específica de algumas argilas e caulins cerâmicos brasileiros pelo método de azul de metileno e sua correlação com ensaios tecnológicos. Cerâmica, v. 20, n. 79, p.305-311, 1974. 
COELHO, A. C. V., SOUZA SANTOS, P. Argilas especiais: argilas quimicamente modificadas - uma revisão. Quim. Nova, v. 30, n. 5, p.1282-1294, 2007.

FERREIRA, H. S. Otimização do processo de organofilização de bentonitas visando seu uso em fluidos de perfuração não aquosos. Campina Grande, PB: UFCG, Engenharia de processos, 2009. (Tese de Doutorado).

GOPINATH, T. R., SCHUSTER, H. D., SCHUCKMANN, W. K. Clay mineralogy and geochemistry of continental bentonite and geological implication Boa Vista, PB. Revista Brasileira de Geociências, v. 18, n. 3, p. 345-352, 1988.

GOPINATH,T. R., SCHUSTER, H. D., SCHUCKMANN, W. K. Modelo de ocorrência e gênese da argila bentonitas de Boa Vista, PB. Revista Brasileira de Geociências, v. 11, n. 3, p. 185-192,1981.

MAHTO, V., SHARMA, V. P. Rheological study of a water based oil well drilling fluid. Journal of Petroleum Science and Enginnering, v. 45, p. 123-128, 2004.

MENEZES, R. R., MARQUES, L. N., CAMPOS, L. A., FERREIRA, H. S., SANTANA, L.N.L., NEVES, G.A. Use of statistical design to study the influence of CMC on the rheological properties of bentonite dispersions for water-based drilling fluids, Applied Clay Science, 2010.

MENEZES, R. R., CAMPOS, L. F. A., FERREIRA, H. S., MARQUES, L. N., NEVES, G. A., FERREIRA, H. C. Estudo do comportamento reológico das argilas bentoníticas de Cubati, Paraíba, Brasil. Cerâmica, 55, p. 349-355, 2009.

MENEZES, R. R., ÁVILA JÚNIOR. M. M., SANTANA, L. N. L., NEVES, G. A., FERREIRA, H. C. Comportamento de expansão de argilas bentoníticas organofílicas do Estado da Paraíba. Cerâmica, 54, p.152-159, 2008.

PETROBRAS. Viscosificante para fluidos usados na exploração e produção de poços de petróleo e gás. Norma EP-1EP-00011-A, 2011.

SILVA, A. R. V., FERREIRA, H. C. Argilas bentoníticas: conceitos, estruturas, propriedades, usos industriais, reservas, produção e produtores/fornecedores nacionais e internacionais. Revista Eletrônica de Materiais e Processos, v. 3, n. 2, p.26-35, 2008.

SOUSA, F. K. A. Estudo de composições de argilas organofílicas para fluidos de perfuração de poços de petróleo em águas ultraprofundas. Campina Grande, PB: Engenharia de Materiais, UFCG, 2010. 180p. (Tese de Doutorado).

SOUZA SANTOS, P. Ciência e tecnologia de argilas. São Paulo: Editora Edgard Blücher, 1992. v. 2, p. 609.

Artigo recebido em 22 de agosto de 2011. Aprovado em 12 de agosto de 2013. 